\title{
Rule of Law in the Philippines: The Reproductive Logic of Elite Democracy*
}

\author{
Fernando P. Gonzaga
}

\section{ABSTRACT}

Confronted by mounting allegations of corruption, electoral fraud, and abuse of executive power, the government of Philippine President Gloria Macapagal-Arroyo (2001-2010) called on critics and demonstrators to cease their dissent and uphold the "rule of law." Amid this unsettling void in political authority, the Philippine Supreme Court used its judicial power to promulgate rules that would enforce the "human rights" of citizens. By analyzing the speeches of President Arroyo and Supreme Court Chief Justice Reynato S. Puno (2006-2010), the paper will examine how this dynamic plays out on the terrain of signification, where large political bodies, which claim to speak for the multitude of Filipinos, struggle over the parameters of sovereign power or the idea of what the government "should do" and "cannot do."

KEYWORDS: Philippine politics, Arroyo, Supreme Court, sovereign power, human rights, extrajudicial killings

For most of the initial decade of the twenty-first century, the Philippines was said to be living under the pall of impunity, haunted by the specter of a justice that was perpetually withheld. From Gloria Macapagal-Arroyo's ascension to the Presidency in January 2001 to the conclusion of her term of office in June 2010, political activists and news journalists were killed in increasing numbers, often in broad daylight and by assailants who were never caught or convicted. Although the Arroyo administration in its official rhetoric condemned these extrajudicial killings and enforced disappearances, it also

*This paper was presented at the 11th Annual Cornell University Southeast Asia Program Graduate Student Conference in October 2008. 
Fernando P. Gonzaga, "Rule of Law in the Philippines: The Reproductive Logic of Elite Democracy"

refrained from acting decisively. It instead devoted its energies and resources to combating allegations of corruption, electoral fraud, and abuse of executive power, frequently calling for its opponents to cease their dissent and uphold the "rule of law." To fill this apparent political void, in which the state failed to protect the "life, liberty, and security" of the populace, the Philippine Supreme Court adopted an expanded notion of its judicial power in 2007 to promulgate rules that would enforce the "human rights" of citizens against the abuse of sovereign power. The default reaction of the press and the populace was to laud the Supreme Court and its judicial activism for saving Philippine democracy; however, the implications of these actions were actually contrary.

Previous studies on authoritarianism in the Philippine political sphere had dwelt on the autocratic actions of public officials. An example would be Alfred McCoy's essay in the volume Philippine Colonial Democracy on the paradigmatic despotism of Commonwealth President Manuel Quezon. Few studies interrogate how, in an elite democracy like that of the Philippines, the workings of authoritarianism can extend beyond the individual and organizational dimension of presidential decree or state violence. It is this dynamic that I aim to study, namely, how the sphere of democratic action in the Philippines translates to the conflict among large political bodies that claim to speak for the multitude of Filipinos. Seeing the activities of the state as merely part of the operations of symbolic governmentality, I would like to explore how resistance against the state can affirm the established order. Through a close reading of the speeches of President Gloria Macapagal-Arroyo and Supreme Court Chief Justice Reynato S. Puno, I will examine how this dynamic plays out on the terrain of signification and affect. This is where the Philippine state and Supreme Court struggle over the parameters of executive or sovereign power, and over the idea of what the government cannot do and should do.

In January 2001, the constitutional successor Gloria Macapagal-Arroyo became President of the Republic of the Philippines when a non-violent, popular uprising called "EDSA Dos" or "People Power II" ousted the incompetent and corrupt incumbent. Since that moment, however, the Arroyo administration itself repeatedly faced allegations of corruption and abuse of power. It was accused of overpricing infrastructure projects, such as the P1.1-billion (\$26million) Diosdado Macapagal Highway, \$503-million North Luzon Railway, and \$326-million National Broadband Network, and of using public funds such as the Department of Agriculture's P728-million (\$17.3-million) fertilizer 
fund for Arroyo's reelection campaign. Aside from being involved in several of these deals, Arroyo's husband and sons were also accused of laundering money from illegal gambling operations.

In June 2005 there emerged tapes of wiretapped phone conversations between Arroyo and a Commission on Elections commissioner during the 2004 national elections; these showed the latter assuring Arroyo of her winning margin. The majority of her cabinet members resigned and joined the chorus of opposition politicians, civil society groups, and leftist organizations that rallied on the streets to demand for her ouster. Due to this threat of another People Power uprising, combined with surveys consistently showing its widespread unpopularity, the Arroyo administration resorted to illicit means to ensure its survival. It rewarded loyal friends and allies, even those allegedly involved in corruption and electoral fraud, with administrative positions. It bribed members of Congress so that impeachment cases filed against Arroyo were dismissed as "insufficient in substance." Equating all progressive civil society actors with "communists," Arroyo vilified her opponents as "enemies of the state."

With the protests against her administration continuing unabated, Arroyo adopted a Calibrated Preemptive Response policy in September 2005, which enabled the police to break up large assemblies of people. This policy was later declared unconstitutional by the Supreme Court. In response to Senate inquiries into the different allegations, she issued Executive Order 464 , which required cabinet members summoned before Congress to seek "prior consent" from the Office of the President before divulging "confidential or classified information" that could hinder state security or public interest. While presented as a way of protecting the rights of public officials and the principle of separation of the executive and legislative branches, it only lessened government transparency and accountability.

When disgruntled military officers and soldiers were caught planning to join the organized protests on the $20^{\text {th }}$ anniversary of the February 1986 People Power revolt, Arroyo declared a State of National Emergency with Presidential Proclamation 1017, claiming to have uncovered a conspiracy between the extreme left and extreme right to stage a coup d'état. She denounced the actions of her opponents for hampering the economy, aiding in the overthrow of democracy, and "sabotaging the people's confidence 
Fernando P. Gonzaga, "Rule of Law in the Philippines: The Reproductive Logic of Elite Democracy"

in government and their faith in the future of this country." In blaming the national media for "recklessly magni[fying]" the situation, she recognized the potency of signification and representation in shaping public opinion and the need to control them. PP 1017, whose explicit purpose was to quell insurrection or rebellion and "to enforce obedience to all the laws and to all decrees, order and regulations promulgated by me personally or upon my direction," temporarily granted the state the unconditional authority to arrest opposition leaders and militant leftists as well as to close news bureaus that failed to regulate their content according to the administration's guidelines for responsible journalism. The Supreme Court later ruled that such actions by the state were unconstitutional.

State inaction likewise worked to suppress dissent, such as in the case of the Arroyo administration's hesitance to act decisively on the problem of extrajudicial killings and enforced disappearances. According to Philip Alston, the United Nations Special Rapporteur on Extrajudicial, Summary or Arbitrary Executions who visited to the Philippines to investigate, these extrajudicial killings and enforced disappearances clearly were planned with the intent to sow fear in dissenters (6); in effect, "narrow[ing] the country's political discourse" (Alston 8). His report highlighted the seemingly coincidental link between these killings and disappearances and the state's counterinsurgency operations. For example, the report described how, in Nueva Ecija, Central Luzon, the Armed Forces of the Philippines occupied a barangay (the smallest administrative unit in the Philippines and the modern equivalent of the pre-colonial barrio) and attempted to identify the members of the civil society groups working there, which it uncritically considered to be fronts for the Communist Party of the Philippines. After constructing an "order of battle," the AFP interrogated individuals named on this list and ordered them to surrender, all without without the assumption of innocence. Many of the individuals listed in the "order of battle" disappeared or are killed.

The Arroyo administration tried to deal with the challenges to its continued rule by relying on the consolidation of support from its political allies, on the application of the law and of violence against combative opponents, and on the manipulation of symbols to stop ambivalent citizens from forming a collectivity that could topple the state. To preserve itself, the Arroyo administration needed to contain the force-People Power-that established its rule in the first place. 
The Arroyo administration attempted to restrict the political action of the population to non-subversive areas by deploying the police and re-inscribing the law. The media and anti-administration elements condemned these efforts as being despotic, while the Supreme Court ruled them to be unconstitutional. Due to the prevailing negative attitude towards unsanctioned state violence, the Arroyo administration had to carefully negotiate the thin perceptual boundary between justified use and blatant abuse of sovereign power. Its response was constrained by the current global political landscape, which is shaped by social media, the presence of transnational organizations, and the general concern for human rights. Unsanctioned state violence no longer had legitimacy in the public discourse engendered by this political landscape. Filipinos still bore the trauma from the Martial Law regime of Ferdinand Marcos, in which a curfew was imposed, the press was closed, businesses were seized, and dissenters were imprisoned, tortured, and had disappeared.

Surveys consistently showed that a large majority of Filipinos were dissatisfied with Arroyo's presidency. To prevent this dissatisfaction from translating into widespread demonstrations that could include typically unengaged sectors of Philippine society such as the business community, the Church hierarchy, and the urban middle class, the Arroyo administration turned to subtler means of control that worked on the subconscious and affective levels. Elizabeth Povinelli has written about how the contemporary multicultural Australian state invoked the popular shame over the injustice of a colonial past to summon a national-collective will. In a similar vein, the Arroyo administration drew on the moral and emotional connotations of the rhetoric of the "rule of law" to confrontchallenges to its survival, although its aim was to prevent a national-collective will from developing into a potent counterforce.

In one important speech in June 2005 that responded to former President Corazon Aquino's call for Arroyo to resign voluntarily due to allegations of electoral fraud, Arroyo stressed the urgency "to move away from political bickering to doing what the people of the Philippines expect their leaders to do and that is get our economy moving and ensure the delivery of essential services" (Arroyo, "PGMA...resignation"). Claiming to be speaking in the best interest of the nation, she assumed to know what the majority of Filipinos want from those whom they have tasked with directing the country. This practice of interpreting the desires of the multitude as the interests of the majority could also be found in her speech in November 2007 when military officers 
Fernando P. Gonzaga, "Rule of Law in the Philippines: The Reproductive Logic of Elite Democracy"

on trial for rebellion, along with a few opposition politicians, barricaded a deluxe hotel in Makati City:

It is clear that the actions of those few desperate men reveal just how out of touch they are with the hopes and dreams of the average Filipino. Filipinos want political stability, a bright economic future and social justice. The actions of those misguided men undermine each and every one of the genuine aspirations of real Filipinos. Instead of working to bring together the nation by working within our democratic process, their actions merely are fuel for selfish motives for personal gain. (Arroyo, "President...Armed Forces")

Again, she claimed to know without any error in interpretation all the "genuine" "hopes and dreams" of "average" or "real Filipinos," which her "misguided" and "desperate" opponents were "out of touch" with and therefore ended up "undermin[ing]." She presented this picture of herself as having had overcome a supposed communication gap between the people and their leaders, which is a fundamental concern in representative democracy. In referring to the rest of the population as "real Filipinos," she was suggesting that unlike her, the political actors who opposed her administration were ensnared in a narcissistic fantasy. Lumping them together with other dissenters, armed communists, and terrorists, she tried to deflect the blame for the country's problems to this aggregate of her opponents. The contrast made between their selfishness and her concern for the principles of democracy and the interests of the majority illustrates that political authority issues in part from the legitimacy to speak for the multitude.

Here, as in other speeches, Arroyo repeatedly emphasized the significance of the economy, which she called "the people's business" (Arroyo, "PGMA...resignation"). She claimed that her administration had successfuly managed this and the proof was the rise in Gross Domestic Products (GDP), a robust currency, and growth in foreign investments. Shaping the public perception of the country's economic performance was a tool to mitigate dissent. She viewed that the state's tasks were to stimulate economic progress and to provide basic services to its citizens (Arroyo, "PGMA...resignation"). In establishing an integral link between the progress of the Philippine economy and the improvement of the lives of Filipinos, she posited that those who hindered economic progress were consequently ruining the lives of the majority. When she declared that 
Filipinos desired economic progress above all, she was implying that illegal activities such as corruption, electoral fraud, and abuse of power were excusable as long as the two tasks of the state were met. Repeatedly emphasizing the significance of the economy allowed her to tap into the shame felt by many that the country is being left behind by its Southeast Asian neighbors, into the mythic nostalgia that the economy before Martial Law was second only in Asia to Japan's, and into the idealistic aspiration that the Philippines can develop into a First World country. To prove that the national economy was performing well under her administration, she constantly cited government statistics. These quantitative interpretations of the material conditions of existence were based on her administration's own economic measures. In lamenting the nation's wasted potential-what Filipino writers have called its "embarrassment of riches"-Arroyo underscored that the country should not allow its current political troubles to spoil the opportunity it had at that very moment to prosper (Arroyo, "PGMA...Peace Rally"). In this way, the telos of economic progress had become the sole concern for the country's future, and the Arroyo administration alone possessed the means to achieve this .

In her June 2005 response to the clamor for her resignation, Arroyo characterized the actions of protestors as "caus[ing] deep and grievous harm to the nation because they undermine our democratic principles and the very foundation of our constitution. Once again, we're subverting the rule of law and perpetuating a system that's broken" (Arroyo, "PGMA...resignation"). She considered these protestors to be nothing but "destabilizers" and "troublemakers" and their dissent to be simply "political bickering," an insurmountable barrier that she equated with the "broken" political system that kept the economy from "moving" (Arroyo, "PGMA...resignation"), impeded the prosperity of the people (Arroyo, "PGMA...Barangay"), and jeopardized the future of the country. She quipped: "walang mangyayari kung papayagan nating manggulo ang mga nanggugulo [nothing will be accomplished if we allow the troublemakers to cause trouble]" (Arroyo, "PGMA...Barangay"). By denouncing the broken political system, she gave the impression that she and her administration stand apart from it and can therefore be spared from any changes to the political system. In the same speech, in which she congratulated barangay officials for their steadfast support of her administration in the midst of its crises, she pleaded for the country to focus and to unite: "Ang kinabukasan ng ating bansa, the future of our country, lies in our unwavering focus. Dapat nakatutok tayo. Dapat determinado tayo to apply the rule 
Fernando P. Gonzaga, "Rule of Law in the Philippines: The Reproductive Logic of Elite Democracy"

of law... [The future of our country lies in our unwavering focus. We should be focused. We should be determined to apply the rule of law...]" (Arroyo, "PGMA...Barangay"). Through these links in signification, the future of the country seemed to depend on the absence of troublesome dissent, which was tied to the application of the rule of law. The supposed link between the country's future and political acquiescence could likewise be seen in another speech from 2005. Arroyo reacted to the Senate's decision to continue its investigations into electoral fraud despite the House of Representatives' dismissal of the impeachment case against her. Evoking a Manichean narrative of stark contrasts, she imagined two different "Philippines"': one "poised for economic take-off" and the other beset by a "poisoned political system" (Arroyo, "PGMA...Kaanak"). Caught in this fallacy of false dilemma, dissent is equated with a self-serving lust for power, and therefore is always a hindrance to economic progress.

Arroyo rebuked dissenters not only for obstructing the work of the government and the economy but also for subverting the rule of law and the principles of democracy, both of which remained undefined abstractions. According to her interpretation of political reality, these people had "deep[ly] and grievous[ly]" wounded the nation (Arroyo, "PGMA...resignation") as though it were an organism that could be hurt. Such a vivid image allowed Arroyo to elicit sympathy for her administration and anger against her opponents. Through a series of associations, she tried to establish that freedom and democracy would not thrive without the constitution and the law (Arroyo, "PGMA...resignation"; Arroyo, "PGMA...Peace Rally"): "This is a democracy that's held together by the Constitution and the rule of law. The Philippines has fallen into a dangerous pattern where the answer to every crisis is to subvert due process rather than work within the system. This must stop" (Arroyo, "PGMA...resignation"). Arroyo fashioned a picture of the Philippines as a tragic nation trapped in the "dangerous" repetition of history where crises are resolved by disregarding the established legal and political system. This picture was meant to exploit the new wariness of Filipinos about People Power uprisings, which had simply substituted one set of traditional politicians for another without transforming the dominant political and social order.

Arroyo asked her opponents to allow "due process" to work and the "rule of law" to prevail, instead of demonstrating on the streets and demanding for her resignation, which she viewed as actions that could wreck political 
institutions and cause widespread chaos. Arroyo asserted that in a democracy, "natural lang ang magkatalong pananaw at posisyon" [conflicting views and positions are natural]. Conflicting views and positions are supposedly acceptable within the democratic space as long as they can be settled peacefully. When they cannot be settled peacefully, the courts are there to deal with them (Arroyo, "PGMA...NEDA"). This idea of democracy sees the exercise of power as occuring through discussion, the failure of which only transfers political action to the juridical arena. Democracy has definite bounds circumscribed by constitutional law that prevents it from dissolving into chaos. The Arroyo administration deployed this argument to convince its opponents to halt their demonstrations and wait for the impeachment process in Congress to unfold. By being restricted to language and legality the exercise of power could not threaten the state.

When Arroyo's allies dismissed the impeachment case against her as "insufficient in substance" without even seeing the evidence, they closed off a crucial constitutional recourse. As new allegations about the Arroyo administration's purported illegal activities surfaced, the street demonstrations continued and the Senate opened investigations into these accusations. When her critics made allegations that a contract with the Chinese government to develop a national broadband network was ridden with "kickbacks," Arroyo responded by accusing them of peddling baseless fabrications: "Ang paglilitis hindi dinadaan sa tsismis. Ang paglilitis dinadaan sa ebidensiya. Merong sapat, merong karapat-dapat na korte para doon" [Trials should not be based on gossip. Trials should be based on evidence. There are enough mechanisms for that. There is a proper court for that] (Arroyo, "PGMA...Peace Rally"). She suggested that instead of disrupting the routines of society with demonstrations or wasting the resources of the legislature on investigations, they should acquiesce because the appropriate political and legal mechanisms for handling these problems were already in place. In a similar speech in September 2005 explaining why she must "put [her] foot down" and ban protestors from gathering in public and cabinet officials from appearing before Congress, she averred that Senate inquiries were being done in aid not of legislation but of "destabilization," through "speculation, hearsay and half-truth," and that the government was being "disabled by the politics of insult" by "those who want to grab power" (Arroyo, "PGMA...Kaanak"). The Arroyo administration, using the desire among the populace for democratic political institutions to function as they would in First World countries, reshaped the signification 
Fernando P. Gonzaga, "Rule of Law in the Philippines: The Reproductive Logic of Elite Democracy"

of the rule of law for the purposes of preserving the state. This logic of political survival assumed that establishing the rule of law meant ignoring all the allegations against the administration so that the state could concentrate on its principal task of managing the economy. Upholding the rule of law meant permitting Gloria Macapagal-Arroyo to finish her term as President without holding her administration accountable for any of its alleged abuses.

The Arroyo administration reduced People Power to the plane of signification in order to avoid its impact. Appealing to the pride, shame, and frustration felt by Filipinos regarding their country and its current situation, Arroyo argued in a speech she delivered on the anniversary of the 1986 People Power uprising that the change in government her opponents wanted to bring about through another People Power uprising would only damage the country's international reputation:

Yung mundo pinagdiriwang ang Edsa 1. Yung mundo pinayagan ang Edsa 2. Yung mundo hindi patatawarin ang Edsa 3. Sasabihin ng mundo, ano ba yang Pilipinas? Pinakamagaling na manggagawa sa buong mundo kaya hinahanap sa buong mundo tapos parating binabaril ang sarili at hindi matatag? Kung ganon, sino ang darating na investor dito? [The world celebrated Edsa 1. The world tolerated Edsa 2. The world will not forgive us for Edsa 3. The world will say, what's wrong with the Philippines? Because its workers are the best in the entire world, they are sought after by the entire world. But then it always shoots itself and does not stand firm. If that's the case, which investor would want to come here?]. (Arroyo, "PGMA...Peace Rally")

Dissent became the scapegoat that must be expelled from the democratic space so that the foreign investors, upon which the Philippine economy relies heavily, would not be frightened away. Investors were pictured to be seeking the rule of law (Arroyo, "PGMA...NEDA") and an environment suitable for business, which meant no market fluctuations caused by political turmoil. Arroyo thus claimed to speak not only for the Philippine population but also for the foreign community, with which she supposedly had intimate ties because she was the head of state. In declaring that the true spirit of People Power is expressed in the principles of democracy and the rule of law, she attempted to contain its potential for revolutionary action within abstractions such as freedom, democracy, and law. 
In assuming that People Power is a legacy of the heroes of the Philippine Revolution who devoted their lives to unite the nation and fight for its independence, the Arroyo administration accused its critics of of degrading their memory and sacrifice. Addressing a brotherhood of patriots, she praised the group for exemplifying the virtue of love for nation, which was in stark contrast to her opponents: "Talagang importante na yung pagmamahal sa ating bayan bilang isang bansa, nationhood, ay hindi lamang nandoon sa inyong mga ninuno, hanggang sa inyo, hanggang dapat sa mga dumarating na henerasyon. [It is truly important that love for our people as a nation was not merely present in your ancestors, but should continue to be present in you and in future generations.]" (Arroyo, "PGMA...Kaanak"). She envisioned a community of love and patriotism that included the heroes of the Philippine Revolution; those who continued to dissent were excluding themselves from this.

The Arroyo administration, by employing techniques of signification that linked popular dissent with economic and political degradation, turned the country's troubling conditions into a trauma that could only be overcome by entrusting the government. Arroyo's speeches employed certain assumptions, about how the national economy functioned, that entailed the need to enforce the rule of law in order to assure economic productivity. This meant that the government must project to the world a tranquil image of Philippine politics with no noticeable dissatisfaction and dissent. This involved allowing the system to work even if a significant number of the populace continued to be marginalized and oppressed. These techniques of signification severed the bond between affect and action and transferred political responsibility from the Filipino multitude to their elected government.

Similar to President Arroyo, the Philippine Supreme Court also harnessed the potency of signification to redefine its role in government. Given that in the Philippines the President has the authority to appoint justices without seeking the approval of Congress, many perceive the Supreme Court to simply be an extension of the executive branch. Such was the case during the Marcos dictatorship, when the Supreme Court legally affirmed Marcos' implementation of Martial Law and his changes to the Philippine Constitution, thereby legitimizing his rule. Despite unequivocal reports from the United Nations, the European Commission, and Amnesty International that held the Philippine government accountable for extrajudicial killings and enforced disappearances of activists and journalists, neither the state nor the congress were 
Fernando P. Gonzaga, "Rule of Law in the Philippines: The Reproductive Logic of Elite Democracy"

willing to act decisively against these acts. To compensate for this seeming political void, the Supreme Court expanded its notion of judicial power, which Alexis de Tocqueville defined as "the right of the judges to found their decisions on the constitution rather than on the laws" (qtd. in Kommers 53). By upholding the principle of judicial review, which balances the exercise of power among the different branches of the Philippines' American-style political system, the Supreme Court supposedly provided a counterforce against the abuse of power by the state. According to Chief Justice Reynato S. Puno the 1987 Constitution granted the Philippine judiciary "more muscular strength in dealing with the non-use, misuse, and abuse of authority in government" (Puno, "View from the Mountaintop" 3). Article VIII, Section 1 of the Constitution states that:

Judicial power includes the duty of the courts of justice to settle actual controversies involving rights which are legally demandable and enforceable, and to determine whether or not there has been grave abuse of discretion amounting to lack or excess of jurisdiction on the part of any branch or instrumentality of the Government.

This expanded notion of judicial authority meant that constitutional rights were no longer merely "declaratory" in character but to be "enforced" in practice (Bernas). Section 5 enabled the judiciary to promulgate rules or laws that would protect and enforce such rights, a power that had previously been reserved only for legislature. The Supreme Court used its new judicial power as a means to strengthen the justice system, to demand from the government "a high standard of official conduct," and to combat the culture of impunity that had afflicted the country (Puno, "No Turning Back" 3). This Supreme Court, organized a National Consultative Summit on Extrajudicial Killings and Enforced Disappearances in July 2007 and afterwards crafted rules for the writ of amparo, though it did not have any explicit statutory support in the Constitution. In contrast to the writ of habeas corpus, which entails the production of a human body that officials may claim not to have in their custody, the writ of amparo makes it an obligation for the government to perform actively its constitutional duty of protecting and enforcing democratic rights.

In its rules, the writ of amparo is depicted as a powerful legal recourse that can grant deliverance to those who have no other recourse, "a remedy available 
to any person whose right to life, liberty and security is violated or threatened with violation by an unlawful act or omission of a public official or employee, or of a private individual or entity." Specifying that the writ is applicable not only to acts but also to threats and omissions, the rules highlight omissions by public officials or employees. In other words, the writ is designed to address the failure to perform the duties of government. The rules of the writ of amparo also distinguish between "public officials and employees" and "private individuals and entities" as though the public sphere where politics occurs were the sole responsibility of the government, while the private sphere which individuals inhabit were insulated from politics to enable them to pursue life, liberty, and security unfettered. Here, the boundary that separates the public from the private is not a matter of community and individual; it is rather the point at which the political passes into the non-political or apolitical.

The writ requires the government to describe the "steps and actions" (Philippine Supreme Court 5) it has taken to investigate the unlawful act, threat, or omission as well as the "manner and conduct" of the investigation (Philippine Supreme Court 3). All the information and evidence in the possession of the government must be presented to the court. Unlike private individuals who are expected to demonstrate only "ordinary diligence," public officials must prove that they have exercised "extraordinary diligence" in the conduct of their duty (Philippine Supreme Court 11). Public officials cannot escape accountability due to the inclusion of anticipatory mechanisms that prevent them from delaying the legal process or submitting a blanket denial. Enabling citizens to hold the government accountable for its actions, the rights claim enacted by the writ of amparo becomes the means by which the multitude can recuperate their idea about the possibilities of government. It is the opening through which they can found the conditions for a new political community where the contractual relations between the citizens and the state would work democratically. However, rights claims are not necessarily emancipatory, Wendy Brown argues, but are rather more ambivalent in that their character depends on the specific networks of power in which they are applied. Concentrating attention and resources on holding the government accountable places the responsibility for protecting and enforcing the autonomy of individuals in the state and the judiciary. Enclosed within the private sphere, where they can freely pursue their interests, citizens relinquish their capacity for political action to their elected representatives and public officials. While the efforts made by the Supreme Court to reinforce rights claims may 
Fernando P. Gonzaga, "Rule of Law in the Philippines: The Reproductive Logic of Elite Democracy"

appear to emancipate the multitude from the force of sovereign power, these efforts may actually achieve the opposite outcome, as can be discerned in the speeches of Supreme Court Chief Justice Reynato S. Puno.

In a speech regarding the Supreme Court's defense of the freedom of the press against the threat of extrajudicial killings and enforced disappearances, Chief Justice Puno stressed the urgency of confronting the culture of impunity: "Unless and until we do something to submerge this pernicious culture, these attacks will continue to litter our collective consciousness with corpses of people who are bearers of truth" (Puno, "Freedom of the Press" 1). The truth inscribed in the bodies of witnesses is rendered mute when these witnesses are mercilessly killed. Without justice, their "corpses" remain visible in the public imagination, but any access to the truth they bear is refused. Only through the Supreme Court's deliverance will individuals be able to excavate the truth and carve out a democratic space in the "collective consciousness." The we "who can do something" refers to "the advocates, experts, journalists, and jurists coming from all over the world who share the same concern over the rampant human rights violations around us" (Puno, "Freedom of the Press" 1) and not to the multitude of Filipinos against whom these violations are being committed. It is the task of the former and not the latter "to strengthen democracy." With the multitude of Filipinos being portrayed as powerless, political action seems to be limited to the intervention of "the advocates, experts, journalists, and jurists."

Like Arroyo, Puno creates the impression that the Supreme Court stands above the broken political system and can be the one tasked with bringing it into proper order. This compelling image is evident in the very first sentence of "The View from the Mountaintop," his opening speech at the National Consultative Summit on Extrajudicial Killings and Enforced Disappearances, with the first-person I's Promethean act of "blowing the trumpet call" for the Summit (Puno, "View from the Mountaintop" 1). The "mountaintop" is supposed to be the vantage point from which the members of the summit can address the problem "above our prejudices, above our predilections, above our prejudgments" (Puno, "View from the Mountaintop" 6) and maybe even above politics. These lines imply in their phrasing that the participants of the Summit-the political actors in the Philippines who wield the power to make changes in the order of things-are not part of the problem and can therefore deal with it objectively and effectively. Although depicted as a democratic 
space free from politics and opportunism, where members of the elite can act in the best interests of the multitude of Filipinos, the mountaintop could actually be the transcendent battleground where the real political actors and factions fight each other for the authority to control the country's resources. According to this conception of Philippine democracy, the exercise of power is restricted to larger institutional bodies-to governmental representatives designated to stand in for the majority when it is the multitude themselves who should be engaged in political action.

With no other political actor or institution capable of intervening in the same manner, deliverance from the "pernicious" problem of extrajudicial killings and enforced disappearances is to be found in the power of the judiciary. For Puno, the new role given to the judiciary by the 1987 Philippine Constitution of protecting and enforcing constitutional rights involves a "revolutionary" (qtd. in Puno, "View from the Mountaintop" 3) transformation of the Supreme Court "from passivity to activism" (Puno, "View from the Mountaintop" 3). Unlike elected officials, who are held captive by their constituencies and dedicate their resources and actions to their reelection, the judiciary is "politically independent" (Puno, "View from the Mountaintop" 5), a claim that consequently masks how the legal system is nonetheless part of a larger network of domination.

Puno's speeches celebrate human rights as being "the last bulwark" in the defense of Philippine democracy (Puno, "No Turning Back" 2), an idea that illustrates how the expectations of the Philippine government have diminished to the point where rights claims have become the only recourse left for terrorized individuals. All those who disregard the value of human rights are likewise debased as being cowardly or apathetic and therefore politically and historically insignificant: "They who seek to remain in the safety of the sidelines when human rights are under assault shall be condemned by history to irrelevance" (Puno, "View from the Mountaintop" 6). More than that, the speeches explicitly deify human rights, in the transcendent capacity of which the multitude must rest their absolute faith and surrender their concrete autonomy: "we are affirming our belief in human rights not only in the abstract; we are affirming that before the universal altar of human rights there can be no atheism, nor agnosticism on our part" (Puno, "View from the Mountaintop" 2). In meticulously establishing the historical continuity of human rights in his speeches, Puno gives human rights the weight of something that has 
Fernando P. Gonzaga, "Rule of Law in the Philippines: The Reproductive Logic of Elite Democracy"

evolved organically not unlike a living being. Human rights are immutable and sacred, being also guaranteed by positive law. Because they possess currency in the eyes of an international community that advocates democracy, their protection and enforcement can serve to enhance the Philippines' global reputation as it strives to become a First World country.

Making human rights claims, however, involves an appeal to a transcendent authority that circumscribes how individuals should behave and act. Talal Asad asserts that rights claims affirm the authority of the state when they seek the intervention of the executive branch in defending human rights. Correspondingly, rights claims affirm the authority of the judiciary when they depend on the legal system to demand action from the state. According to this temporal configuration, the exercise of power is constrained to the filing of rights claims-to the inscription of the visibility of disappearance and death in the legal record. While corpses are rendered visible, other realities are naturalized and concealed. Focusing on the urgency to enforce and protect the constitutional rights of individuals against the abuse of power of the state effectively abstracts politics from the unequal social and economic relations that prevail in the Philippines and the conditions that produce and reproduce these relations (Brown 114). In her reading of Marx's "On the Jewish Question," Wendy Brown contrasts represented freedom and actual freedom, which she equates with the contrast between emancipation and liberation. She explains that when the state emancipates an individual from a constraint to his autonomy, it only abstracts him from the conditions that produced this constraint instead of liberating him from them. The process that resolves in his mind his "relative lack of freedom, equality, and community" reduces his actual freedom to "idealist" "pronouncements of freedom," or in other words, to an empty signifier (Brown 105). The state grants him represented freedom, while abandoning him "to the actual powers that construct, buffet, and subject him" (Brown 107). The desire for autonomy is displaced into the rights-granting mechanisms of government as the government becomes, to paraphrase Marx, "the intermediary" between the multitude and their autonomy (Marx qtd. in Brown 106). To echo Brown, what the state therefore protects and enforce are not the actual life, liberty, and security of the multitude but their circumscribed rights to life, liberty, and security. The state and the law set the terms by which the exercise of power may take place, giving the impression of democracy but in fact containing political action within the parameters of the established order. 
The belief that the problem of extrajudicial killings and enforced disappearances, which are the "spectral remains of the Martial Law regime" (Puno, "Writ of Habeas Data" 7), can be surmounted by countervailing the force of sovereign power has led to the misconception that the country exists in a sacred democratic space that must be defended against structures of tyranny. Although the state has been condemned for its tendency to abuse its monopoly over violence, the effects of domination that appear to emanate from it are not limited to its operations. According to Timothy Mitchell, the state-effect, which is the perception of the state as the rational source of domination, is actually part of the system of means by which the established order is maintained. Nikolas Rose and Peter Miller explain that the different political and social institutions and processes are interconnected in a field of governmentality, the network of power in which the practices, discourses, and mechanisms by which a population and its productive capacities are managed. To avoid confusion, this configuration could be better understood under the name symbolic governmentality, in which the entire play of forces and trajectories in the political sphere, including the circulation of signs and affects, results in the reproduction and perpetuation of the established order. Instead of saving Philippine democracy and liberating the Filipino multitude by contesting the authority of the executive branch, the efforts of the Supreme Court to protect and enforce the human rights of citizens merely work to re-inscribe dissent within the prevailing system of domination and exploitation.

The principle of judicial review exercised by the Philippine Supreme Court is tied to the concept of limited government, which entails that power not be concentrated in a single individual or institution but dispersed among the three branches of government in an American-style political model-the executive, the legislative, and the judicial-through a system of checks and balances (Kommers 54). Instead of limiting or preventing the concentration of power, this model actually results in a situation of expanded government, which concentrates power in a field of governmentality that extends across the different institutions and processes such that they each become an intrinsic component in a self-affecting system of domination and exploitation. For James Madison, one the drafters of the United States Constitution, the ideal was that government would be balanced by a "diversity and multiplication of factions" (Kommers 55), each of which would provide a counterforce to the other. What happens often, however, is that the exercise of power becomes constrained to this terrain of competing factions. 
Fernando P. Gonzaga, "Rule of Law in the Philippines: The Reproductive Logic of Elite Democracy"

Tracing the historical continuity of cacique democracy in the Philippines, Benedict Anderson renders national history as the endless narrative of how the ruling classes have expropriated from the multitude the surplus of their productive capacities and maintained this configuration of hierarchy, domination, and exploitation. The struggles to more democratically distribute the resources of the country, struggles that are caught in the seemingly inescapable repetition of a history reduced to trauma and indolence, are assimilated in less subversive form into the established order. From Anderson's perspective, upholding the rule of law means preserving the established order, which has guaranteed the Filipino oligarchy its political and economic dominance. Seen this way, the rule of law becomes an imagined "democratic space," which affords "room for manoeuvre" to the larger political bodies or factions-such as the politicians, the technocrats, the military, the communists, the oligarchythat compete with one another for control over the production and exchange of resources (Anderson 25). Anderson likens this regime of elite democracy, which removes the multitude of Filipinos from the political equation, to the regulatory logic of the casino:

In any well-run casino, the tables are managed in the statistical favour of the house. To keep drawing customers, the owners must provide them with periodic, even spectacular successes. A win is a splendid confirmation of the player's skill and heaven's favour. A loss demonstrates his/her misfortune or ineptitude. Either way, it's back to the tables as soon as possible. So with the blackjack of cacique democracy. Each local triumph for reform promises a rentier future; each loss signals miscalculations or ill luck. At the end of the week or the year, however, the dealer is always in the black. (30)

The apparent unpredictability of gambling in the casino is paralleled with the perceived contingency of participating in Philippine democracy, where every Filipino seems to be embraced with the promise of equal freedom and opportunity. Any ordinary citizen can run for political office in local and elections where a large majority regularly votes. The uncensored national media are allowed free rein to dictate the news agenda even if the issues addressed may be unfavorable to the state. Democracy in the Philippines bears only the semblance of vibrancy, however. According to Anderson's account, although many ordinary Filipinos may be dissatisfied with the unchanging reality that a privileged minority has more wealth and power than they do, 
they are assuaged and contented by the few opportunities they are granted for improving their lives. Hope arrives in the form of reforms made to the system, which fail more often than they succeed. Because such concessions belong to the reproductive mechanisms of the established order, they never threaten its existence. This semblance of democracy reinforces the prevailing structures of hierarchy, domination, and exploitation by concealing them:

It disperses power horizontally, while concentrating it vertically; and the former draws a partial veil over the latter... Precisely the competition is violently real, it is easy to be persuaded to cheer for, as it were, Arsenal or Chelsea, without reflecting too hard on the fact that both are in the First Division, and that one is watching the match from the outer stands, not playing in it. (Anderson 31)

Using a football analogy, Anderson exposes the logic of exclusion that regulates Philippine politics. As the responsibility for directing the country's future is transferred to a vanguard of leaders and intellectuals, political action is limited to a privileged minority while the rest of the populace is excluded from transforming the conditions of reality.

Instead of being "circulating and relational," the exercise of power is "suppressed" and "congealed" (Brown 112) in conflicting political institutions and factions. In this prevalent situation, the desire of the multitude of Filipinos for democracy can only be articulated and recognized as constitutional rights claims, which affirm the transcendent authority of the state and the law and restrict the exercise of power to language and legality. Through its inscription in a governmental system of domination and exploitation, the mode of justice that can overcome the culture of impunity becomes the means of containing the productive capacities of the multitude for autonomy and transformation. If a People Power revolution were to intervene in the legitimization and reproduction of the system as an immanent event of historical alterity, it would not simply introduce modifications to the leadership or machinery of the prevailing governmental regime but engage in the transformation of the very culture of everyday life that perpetuates the established order of elite democracy. 
Fernando P. Gonzaga, "Rule of Law in the Philippines: The Reproductive Logic of Elite Democracy"

\section{Works Cited}

The 1987 Constitution of the Republic of the Philippines.

Alston, Philip. Mission to the Philippines: Report of the Special Rapporteur on Extrajudicial, Summary or Arbitrary Executions. United Nations Human Rights Council. Geneva: United Nations, 2007. Print.

Amnesty International. Philippines: Human Rights, Political Killings and the Peace Process. London: Amnesty International, 2006. Print.

Anderson, Benedict. "Cacique Democracy in the Philippines: Origins and Dreams." New Left Review 169 (1988): 3-31. Print.

Asad, Talal. "What Do Human Rights Do? An Anthropological Enquiry." Theory E Event 4.4. Web. 20 Mar. 2008. <http://muse.jhu.edu/journals/theory_and_event/v004/4.4asad. html>.

Bernas, Joaquin G. "The Argentinian Amparo." Sounding Board. Philippine Daily Inquirer 10 Sep. 2007. Web. 18 Dec. 2007. <http://opinion.inquirer.net/inquireropinion/columns/ view_article.php?article_id=87599>.

Brown, Wendy. States of Injury: Power and Freedom in Late Modernity. Princeton, NJ: Princeton U.P., 1995. Print.

Kommers, Donald P. "Judicial Review: Its Influence Abroad." The Annals of the American Academy of Political and Social Science 428 (Nov. 1976): 52-64. Print.

Macapagal-Arroyo, Gloria. Executive Order No. 464. 26 Sep. 2005. Web. 1 May 2008. <http://www.ops.gov.ph/records/eo_no464.htm>.

- "PGMA's Message on the earlier statement of Former President Corazon Aquino for PGMA's voluntary resignation." Office of the President, Republic of the Philippines. 8 Jul. 2005. Web. 1 May 2008. <http://www.op.gov.ph/speeches.asp?iid=676\&iyea $\mathrm{r}=2005$ \&imonth=7>.

---. "PGMA's Opening Statement during the NEDA Board Meeting." Office of the President, Republic of the Philippines. 18 Sep. 2007. Web. 1 May 2008. <http://www. op.gov.ph/speeches.asp?iid=1095\&iyear=2007\&imonth=9>.

---. "PGMA's Speech during the $1^{\text {st }}$ Regional Congress of the Liga ng mga Barangay Region III." Office of the President, Republic of the Philippines. 22 Sep. 2005. Web. 1 May 2008. <http://www.op.gov.ph/speeches.asp?iid=705\&iyear=2005\&imonth=9>. . "PGMA's Speech during the $8^{\text {th }}$ Anniversary Celebration of the 'Kaanak 1896." Office of the President, Republic of the Philippines. 30 Sep. 2005. Web. 1 May 2008. <http:// www.op.gov.ph/speeches.asp?iid=707\&iyear=2005\&imonth=9>.

. "PGMA's Speech during the Peace Rally at the Capitol grounds." 25 Feb. 2008. Web. 1 May 2008. <http://www.op.gov.ph/speeches.asp?iid=1198\&iyear=2008\&imonth=2>. . "President Gloria Macapagal-Arroyo's speech during the $72^{\text {nd }}$ Founding Anniversary 
of the Armed Forces of the Philippines." 21 Dec. 2007. Web. 1 May 2008. <http:// www.op.gov.ph/speeches.asp?iid=1168\&iyear=2007\&imonth=12>.

---. Proclamation No. 1017. 24 Feb. 2006. Web. 1 May $2008<$ http://www.news.ops.gov. ph/proc_nol017.htm>.

Mitchell, Timothy. "Society, Economy, and the State Effect." State/Culture: State-Formation after the Cultural Turn. Ed. George Steinmetz. Ithaca, NY: Cornell, U.P., 1999. 76-97. Print.

Philippine Supreme Court. "The Rule on the Writ of Amparo." Manila: Supreme Court, 2007. Print.

Povinelli, Elizabeth A. "The State of Shame: Australian Multiculturalism and the Crisis of Indigenous Citizenship." Critical Inquiry 24 (1998): 575-610. Print.

Puno, Reynato S. "Freedom of the Press: A Touchstone of Democracy." International Conference on Impunity and Press Freedom. 27 Feb. 2008. Address.

---. "No Turning Back on Human Rights." $19^{\text {th }}$ Silliman University Law Alumni Association General Assembly and Alumni Homecoming. 25 Aug. 2007. Address.

---. "The View from the Mountaintop." National Consultative Summit on Extrajudicial Killing and Enforced Disappearances. 16 July 2007. Address.

---. "The Writ of Habeas Data." UNESCO Policy Forum and Organizational Meeting of the Information for All Program, Philippine National Committee. 19 Nov. 2007. Address.

Rose, Nikolas and Peter Miller. "Political Power beyond the State: Problematics of Government." The British Journal of Sociology 43.2 (1992): 173-201. Print.

Fernando P. Gonzaga is a PhD Candidate at the University of California-Berkeley's Rhetoric program who specializes in political thought, visual culture, and Southeast Asian political culture. His book, Globalization and Becoming-nation: Subjectivity, Nationhood, and Narrative in the Period of Global Capitalism (University of the Philippines Press, 2009), examines how the passage from despotic nationalism to transnational capitalism is represented in contemporary Filipino novels. His dissertation, Monsoon Marketplace: Inscriptions and Trajectories of Consumer Capitalism in Singapore and Manila, attempts to map a genealogy of commercial and leisure spaces that have captivated the popular imagination at specific historical junctures. 